\title{
The channels in Storebælt, Denmark: implications of new radiocarbon ages
}

\author{
Ole Bennike ${ }^{* 1}$, Niels Nørgaard-Pedersen ${ }^{1}$ and Jørn Bo Jensen ${ }^{1}$
}

RESEARCH ARTICLE | OPEN ACCESS

GEUS Bulletin Vol 43 | e2019430106 | Published online: 24 June 2019

https://doi.org/10.34194/GEUSB-201943-01-06

The brackish water Baltic Sea and the more saline Kattegat in the north are connected by three straits, Lillebælt, Storebælt and Øresund (Fig. 1). Storebælt (the Great Belt) is the deepest and widest of the straits. The strait is characterised by deeply incised channels that are partly filled by sediments. The water depth in major parts of Storebælt is about $20 \mathrm{~m}$, though in some areas the channels are more than $50 \mathrm{~m}$ deep.

The formation of the channels has been subject to discussion. Andersen (1927) suggested that the channels formed due to strong currents that are still active today or by fluvial erosion during the so-called continental period (Fastlandstiden) in the Early Holocene. At this time, the relative sea level in the region was lower than at present and a huge lake, the Ancylus Lake, which occupied the Baltic Basin, may have drained via Storebælt. Andersen dismissed the idea that the channels were formed by subglacial erosion by meltwater during the last deglaciation. More Recently, Mathiassen (1997) interpreted some of the deposits in the channels as

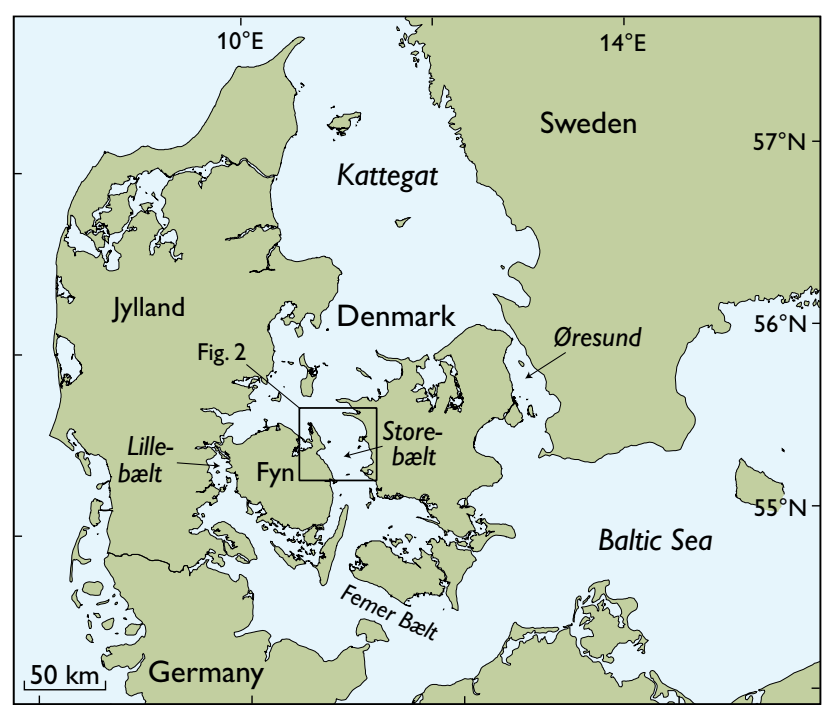

Fig. 1. Map of Denmark and the surrounding area showing the location of the study area. late glacial, a viewpoint followed by Bennike et al. (2004). However, the age of the late glacial deposits in the channels are poorly constrained.

The first studies of sediment cores from Storebælt were carried out by Krog (1973), Winn (1974) and Mathiassen (1997), but these studies concentrated on the Holocene development from mires to lakes to brackish and marine environments. Wiberg-Larsen et al. (2001) documented the presence of Early Holocene river deposits. Here we report on some new ages of macrofossils from late glacial deposits in the Storebælt channels.

In the late 1970s, the Danish state began to map deposits of sand and gravel in Storebælt and several potential aggregate resources were identified east of Romsø. In this part of Storebælt there are two parallel south-north-orientated incised channels. In 2017, new vibrocores were collected by the Geological Survey of Denmark and Greenland (GEUS) as part of a mapping programme of submarine aggregates

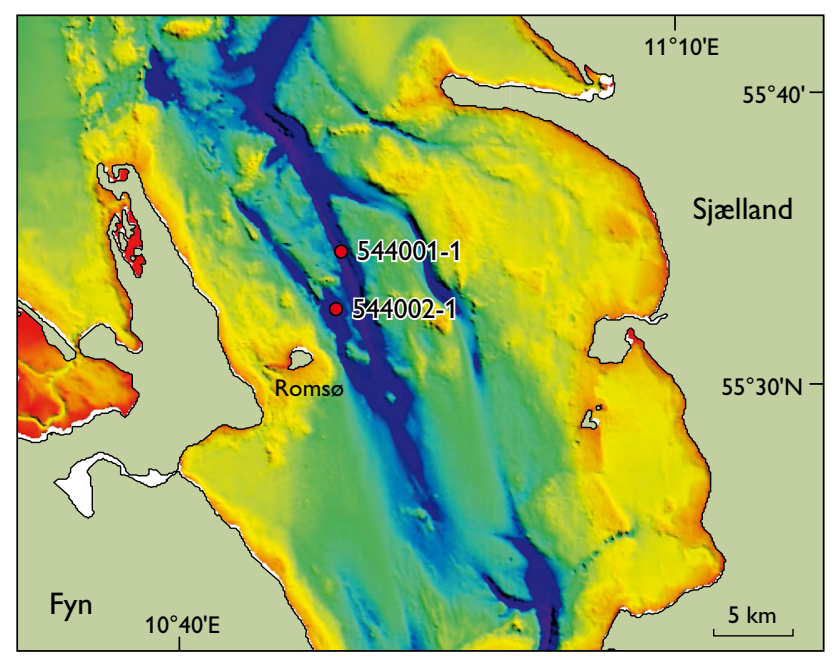

Fig. 2. Bathymetry of the Storebælt region showing the locations of the cores discussed in this paper. Water depth: 0 to $c .50 \mathrm{~m}$. Water depth at core site $544001-1$ is $38.5 \mathrm{~m}$, and at core site $544002-1$ it is $33.6 \mathrm{~m}$. 
Table 1. New radiocarbon ages from Storebælt, Denmark

\begin{tabular}{|c|c|c|c|c|c|c|c|}
\hline $\begin{array}{l}\text { Core } \\
\text { no. }\end{array}$ & N. lat. & E. long. & $\begin{array}{c}\text { Laboratory } \\
\text { no. }\end{array}$ & Species & $\begin{array}{c}\text { Depth } \\
\text { b.c.t. }(\mathrm{cm})^{*}\end{array}$ & $\begin{array}{l}\text { Age }\left({ }^{14} \mathrm{C}\right. \\
\text { years } \mathrm{BP})\end{array}$ & $\begin{array}{c}\text { Calibrated } \\
\text { age (years BP) }\end{array}$ \\
\hline $544001-1$ & $55.571^{\circ}$ & $10.828^{\circ}$ & AAR-29105 & Scirpus lacustris & 201 & $11374 \pm 54$ & $13094-13315$ \\
\hline $544001-1$ & & & Beta-481723 & Betula nana & 447 & $12310 \pm 40$ & $14070-14560$ \\
\hline $544002-1$ & $55.538^{\circ}$ & $10.823^{\circ}$ & AAR-29106 & Phragmites australis & 214 & $9294 \pm 33$ & $10433-10561$ \\
\hline $544002-1$ & & & AAR-29107 & Phragmites australis & 229 & $9455 \pm 38$ & $10604-10741$ \\
\hline $544002-1$ & & & Beta-481724 & B. nana, Dryas octopetala & 375 & $11405 \pm 44$ & $13130-13340$ \\
\hline
\end{tabular}

* Below core top.

† Calibrated to calendar years before present according to the IntCal13 dataset.

for The Danish Environmental Protection Agency. Coring positions were selected from interpretations of shallow seismic data acquired during the initial mapping projects. Two of the new cores from Storebælt contained remains of plants that are typical of late glacial deposits from Denmark. Three samples were submitted for radiocarbon dating, and here we report on the results.

\section{Methods}

An Innomar parametric sub-bottom profiler was used to acquire high-resolution seismic data. Vibrocoring was carried out with a $6 \mathrm{~m}$ long, $10 \mathrm{~cm}$ diameter vibrocorer (VKG-6) from the vessel Skoven. Differential GPS was used to determine coring locations. The cores were cut into $1 \mathrm{~m}$ long sections onboard the ship and sent to GEUS. In the laboratory, the core was split, photographed and described. Half of the cores were archived and the other half were subsampled. Samples for palaeoecological analyses and radiocarbon dating were wet sieved and the residue left on the sieves was analysed using a dissecting microscope. Ages were determined by accelerator mass spectrometry (AMS) radiocarbon dating and calibrated to calendar years before present (1950 CE) according to the IntCal13 data (Table 1).

\section{Results}

Core 544001-1 was collected on the western flank of the western Storebælt channel (Fig. 2). A shallow seismic eastwest profile obtained at the coring site shows thin Holocene marine deposits underlain by late glacial deposits (Lomholt $e t$ al. 2017). The core is $557 \mathrm{~cm}$ long and contains fine-grained sand overlain by silt with granules. These lower units do not contain any macrofossils (Fig. 3). Then follows an almost $400 \mathrm{~cm}$ thick unit of heterolithic laminated mud and clay with plant and animals remains. Plant remains include the land plants Betula nana, Betula pubescens, Dryas octopetala, Selaginella selaginoides and Distichium sp., the reed plant Scirpus lacustris and the water plants Ranunculus hyper- boreus, Hippuris vulgaris, Eleocharis palustris, Potamogeton natans, $P$. perfoliatus, $P$. praelongus, Stuckenia pectinata and S. filiformis. Animal remains comprise Piscicola geometra, Candona sp., Cytherissa lacustris, Valvata cristata, V. piscinalis, Pisidium sp. and Cristatella mucedo. The assemblage is typical of late glacial lake deposits in the region, with the exception of Scirpus lacustris and Stuckenia pectinata (Jensen 1985; Bennike et al. 2004). The warmth-demanding Scirpus lacustris (Schoenoplectus lacustris) is rare in late glacial deposits, though it has been recorded in sediments from the Arkona Basin in the south-western Baltic Sea, where it was dated to $c .12800$ cal. years BP, corresponding to the end of the Allerød chronozone. To our knowledge, there are no previous finds of Stuckenia pectinata from late glacial deposits in Denmark. These plants probably spread northwards by rivers in Storebælt during the Bølling and Allerød chronozones. A sample of Betula nana twigs from a depth of $447 \mathrm{~cm}$ was dated to 14 070-14 560 cal. years BP, corresponding to the Bølling chronozone, and a sample of Scirpus lacustris was dated to 13 094-13 315 cal. years BP, corresponding to the Allerød chronozone (Table 1). The upper $1.5 \mathrm{~m}$ consists of marine bioturbated clay and mud with shells of marine gastropods, bivalves and barnacles, such as Turritella communis, Arctica islandica and Balanus crenatus.

Core $544002-1$ is $500 \mathrm{~cm}$ long and contains sandy diamicton at its base, which is interpreted as glacial till (Figs 3, 4). The till is overlain by laminated mud and homogenous finegrained sand with plant and invertebrate remains. Remains of land plants are dominated by Betula nana but also include Dryas octopetala, Salix sp., Empetrum nigrum, Rumex acetosella and Selaginella selaginoides. Water plants include Ranunculus sect. Batrachium sp., Menyanthes trifoliata, Stuckenia pectinata and S. filiformis. The fauna includes Candona sp., Cytherissa lacustris, Lepidurus sp., Gyraulus rossmaessleri, Pisidium sp. and Cristatella mucedo. A sample of Betula nana and Dryas octopetala remains was dated to 13 130-13 340 cal. years BP, which corresponds to the Allerød chronozone. The flora and fauna are typical of late glacial deposits in the region, except for Gyraulus rossmaessleri, which 
544001-1; water depth 38.5 m

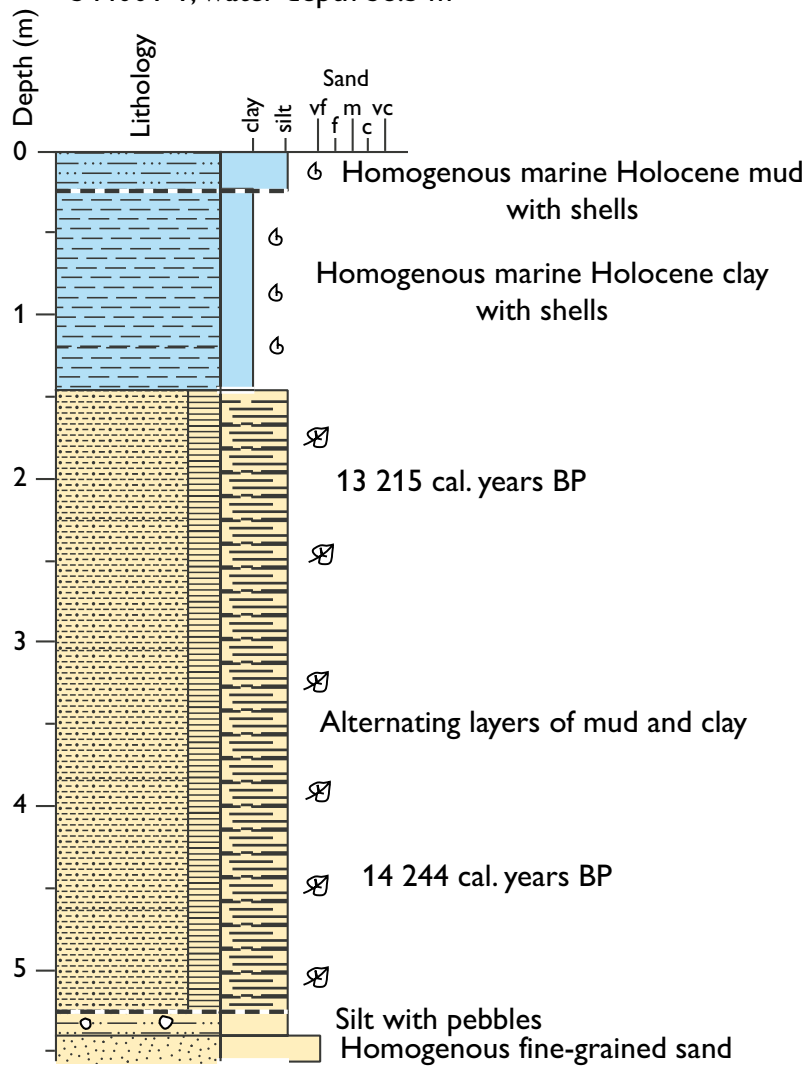

544002-1; water depth 33.6 m

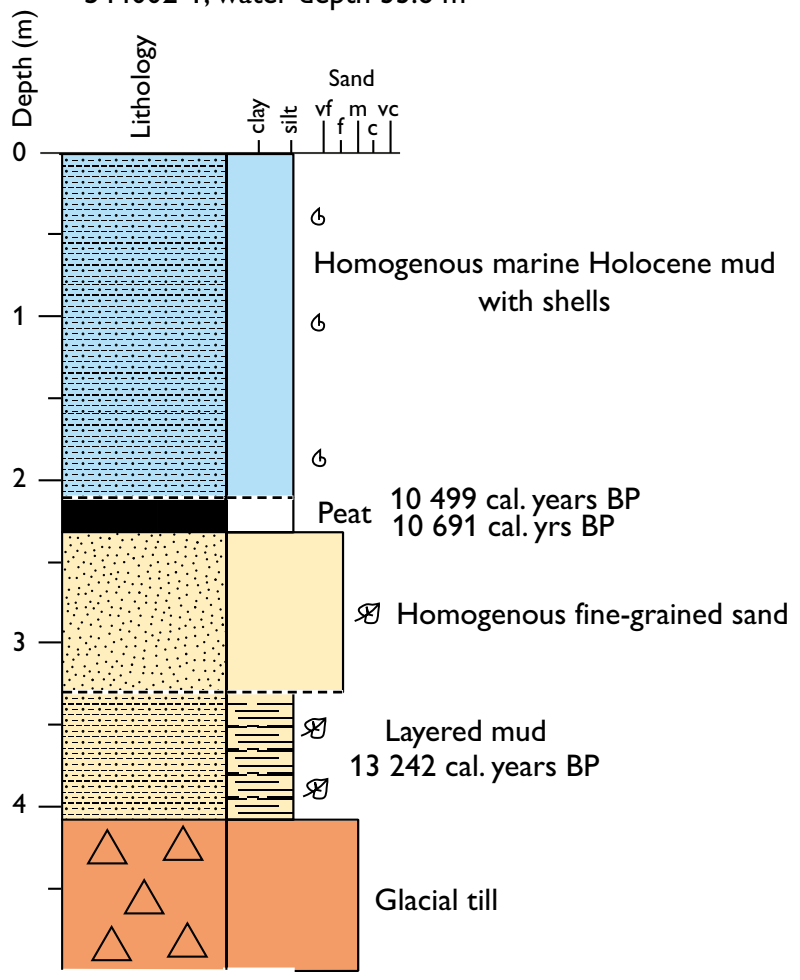

Fig. 3. Sedimentological logs based on sediment cores from Storebælt. Radiocarbon ages are calibrated to calendar years BP (mean probability ages). vf: very fine-grained. f: fine-grained. $\mathbf{m}$ : medium-grained. c: coarse. vc: very coarse.

is rarely recorded, and Stuckenia pectinata as mentioned above. The heterolithic sediments are overlain by a layer of homogenous fine-grained sand with Betula nana remains.

The minerogenic sediments are overlain by a thin layer of peat and gyttja with a rich flora that includes Pinus sylvestris, Betula sect. Albae sp., Populus tremula, Cladium mariscus, Stachys palustris, Ceratophyllum demersum, Najas marina and a fauna with Bithynia tentaculata and Perca fluviatilis. We also found a fragment of a lower jaw of Sorex minutus (pygmy shrew). The fossil assemblage is typical of Early Ho- locene peat and gyttja deposits in the region (Bennike et al. 2004), but Sorex minutus is new to the Early Holocene fauna of Denmark (Aaris-Sørensen 2009). The lower part of the peat was dated to $10604-10741 \mathrm{cal}$. years BP and the upper part to 10 433-10 561 cal. years BP (Table 1). The upper $2 \mathrm{~m}$ of the sediment core consists of bioturbated mud with shells of marine species such as Ammonia beccarii, Balanus crenatus, Tritia reticulata, Nucula tenuis, Arctica islandica, Abra alba, Corbula gibba and Echinocardium cordata.
Fig. 4. Selected part of sub-bottom Innomar profile, with the position of sediment core 544002-1 indicated. The red line separates till from late glacial non-marine sediments. The blue line separates late glacial sediments from marine sediments.

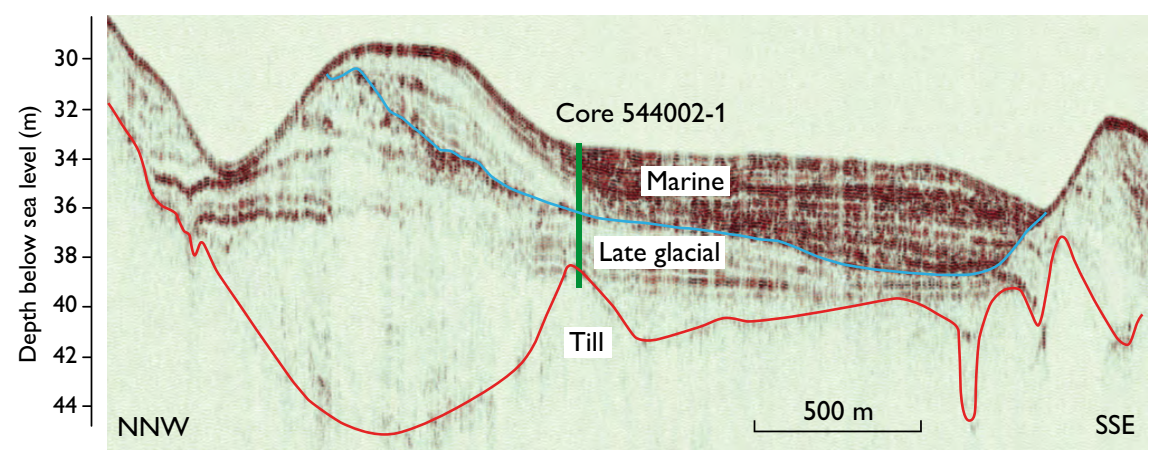




\section{Discussion}

The old age of $c .14200$ cal. years BP from core 544001-1 is noteworthy, because only a few plant remains of this age have previously been radiocarbon dated from late glacial deposits in Denmark. Active glacier ice disappeared from the region between 18000 and 17000 years BP (HoumarkNielsen $e t$ al. 2012). Stagnant ice lingered on in many parts of Denmark and at the same time, temperatures were low in the region until the abrupt warming at the start of the Bølling chronozone at 14700 years BP. The widespread existence of stagnant glacier ice and low temperatures likely delayed the migration and spread of terrestrial plants and animals in the region.

In core 544002-1, a layer of sand is found below the peat deposit. Such sand layers are commonly found below Early Holocene peat layers in the region. In some cores the sand layers contain in situ roots that can be related to the peat layers. In a few cases, the sand layers contain an increasing amount of plant remains in the upper part, and the boundary between the sand layer and the peat layer is often gradual. However, in most cases the sand layers contain no plant macrofossils and the sand-peat boundary is sharp. The sand layer probably reflects a low stand, and the following peat formation can be seen as a consequence of increasing temperatures and more stable soil conditions at the beginning of the Holocene. We interpret the sand layer as late glacial because it contains some remains of Betula nana, but usually such sand layers do not contain plant macrofossils (Bennike et al. 2004).

\section{Conclusions}

The radiocarbon ages discussed in this paper indicate that the deeply incised channels in Storebælt were formed by meltwater during the last deglaciation, as the ice margin receded southwards and huge amounts of meltwater flowed northwards. The channels were probably eroded by water below the ice, near the ice margin. The fossil flora and fauna are typical of late glacial deposits in the region, except for the warmth-demanding reed plant Scirpus lacustris and the water plant Stuckenia pectinata. These species likely colonised the Storebælt area due to northward flowing rivers and grew in the area during the warm Bølling and Allerød interstadials. The ages show that the late glacial deposits in the incised channels are at least in part of Bølling and Allerød age.

\section{Acknowledgements}

This study was supported by Geocenter Denmark. Kristian Gregersen from the Zoological Museum in Copenhagen kindly identified the jaw fragment of Sorex minutus. We are grateful to journal referees Jacob Yde and Jakob Qvortrup Christensen for comments on the manuscript.

\section{References}

Aaris-Sørensen, K. 2009: Diversity and dynamics of the mammalian fauna in Denmark throughout the last glacial-interglacial cycle, $115-0 \mathrm{kyr}$ BP. Fossils and Strata 57,59 pp.

Andersen, S.A. 1927: Storebælt i nutid og fortid. Geologiska Föreningens i Stockholm Förhandlingar 49, 427-437. https://doi. org/10.1080/11035892709444582

Bennike, O., Jensen, J.B., Lemke, W., Kuijpers, A. \& Lomholt, S. 2004: Late- and postglacial history of the Great Belt, Denmark. Boreas 33, 18-33. https://doi.org/10.1111/j.1502-3885.2004.tb00993.x

Houmark-Nielsen, M., Linge, H., Fabel, D., Schnabel, C., Xue, S., Wilcken, K.M. \& Binnie, S. 2012: Cosmogenic surface exposure dating the last deglaciation in Denmark: Discrepancies with independent age constraints suggest delayed periglacial landform stabilization. Quaternary Geochronology 13, 1-17. https://doi.org/10.1016/j.quageo.2012.08.006

Jensen, H.A. 1985: Catalogue of late- and post-glacial macrofossils of Spermatophyta from Denmark, Schleswig, Scania, Halland, and Blekinge dated 13,000 B.P. to 1536 A.D. Danmarks Geologiske Undersøgelse, Serie A 6, 95 pp.

Krog, H. 1973: The early Holocene development of the Store Belt as reflected in a former fresh water basin. Danmarks Geologiske Undersøgelse, Årbog 1972, 37-47.

Lomholt, S., Leth, J.O., Nørgaard-Pedersen, N., Witt, N.H. \& Bennike, O. 2017: Rapportering af 150 boringer udført i spekulative ressourcer. Danmarks og Grønlands Geologiske Undersøgelse Rapport 2017/34, 248 pp.

Mathiassen, D.R. 1997: The changing landscapes of the Storebælt from the retreat of the ice to the sea flood. In: Pedersen, L., Fischer, A. \& Aaby, B. (eds): The Danish Storebælt since the Ice Age: Man, sea and forest. A/S Storebæltsforbindelsen, Copenhagen, 22-28.

Wiberg-Larsen, P., Bennike, O., Jensen, J. B. \& Lemke, W. 2001: Trichoptera remains from early Holocene river deposits in the Great Belt, Denmark. Boreas 30, 299-306. https://doi.org/10.1111/j.1502-3885.2001. tb01049.x

Winn, K. 1974: Present and postglacial sedimentation in the Great Belt Channel (Western Baltic). Meyniana 26, 63-101.

\section{How to cite}

Bennike, O., Nørgaard-Pedersen, N. \& Jensen, J.B. 2019: The channels in Storebælt, Denmark: implications of new radiocarbon ages. Geological Survey of Denmark and Greenland Bulletin 43, e2019430106.

https://doi.org/10.34194/GEUSB-201943-01-06

\footnotetext{
*Corresponding Author: Ole Bennike |E-mail: obe@geus.dk

${ }^{1}$ Geological Survey of Denmark and Greenland (GEUS), C.F. Mollers Allé 8, DK-8000, Aarbus C, Denmark.
} 